\title{
Characteristics and Causes of Disastrous Debris Flows on July 4, 2013, in Shimian County, Sichuan, China
}

\author{
Yonggang Ge, Fenghuan Su \\ Key Laboratory of Mountain Hazards and Earth Surface Processes/Institute of Mountain Hazards and \\ Environment, Chinese Academy of Sciences, Chengdu, China \\ Email: gyg@imde.ac.cn
}

Received 3 March 2016; accepted 22 April 2016; published 25 April 2016

Copyright (C 2016 by authors and Scientific Research Publishing Inc.

This work is licensed under the Creative Commons Attribution International License (CC BY). http://creativecommons.org/licenses/by/4.0/

(c) (i) Open Access

\section{Abstract}

Debris flow is an abrupt phenomenon of earth surface movement and typical disaster in mountainous areas with steep terrace, quantity of loose soil and abundant surface runoff. Intense rainfall and rainstorm easily triggered debris flows and generated huge losses. The disastrous debris flows, on July 4, 2013 at the gullies of Hou, Heilinzi and Xiongjia in Shimian County, Sichuan Province, resulted in 18 casualties and endangering Shimian city with a population of 50,000 . These debris flows were characterized by low viscosity with only $0.9 \%-1.4 \%$ clay soil of less than $0.05 \mathrm{~mm}$, density of $1.77-1.84 \mathrm{t} / \mathrm{m}^{3}$, velocity of $4.4-13.5 \mathrm{~m} / \mathrm{s}$ and discharge of $827-1248 \mathrm{~m}^{3} / \mathrm{s}$, respectively, and also delivered sediment of $16.8 \times 10^{4} \mathrm{~m}^{3}, 12.7-13.5 \times 10^{4} \mathrm{~m}^{3}, 20.5 \times 10^{4} \mathrm{~m}^{3}$ out of the outlet, respectively. These three events all generated a hazard chain, which involved in flash flood, channelized debris flow, dammed lake and outburst flood. The threshold conditions of debris flow blocking Nanya River and forming this hazard chain are that the unit width peak discharge and the deposition volume in river channel are more than $37.0 \mathrm{~m}^{3} / \mathrm{s}$ and $4500 \mathrm{~m}^{3}$, respectively. These debris flows were initiated by intense rainfall with the antecedent rainfall of over 52 $\mathrm{mm}$ and triggering rainstorm of over $36 \mathrm{~mm} / \mathrm{h}$. And, the property losses and casualties mainly originated from impacting and scouring, burying and blocking, highway destructing and river channel rising. The irrational location of constructions and the destruction of under-standard prevention constructions were responsible for loss worsening. It was strongly recommended for mitigating that hazards reassessment, integrated control, emergency plan and integrated risk management were made at mountainous urban areas, especially in high-hazard areas.

\section{Keywords}

Disastrous Debris Flows, Characteristics, Hazards, Causes, Shimian County 


\section{Introduction}

Debris flow, an abrupt earth surface phenomena and process, is extensively distributed and frequently occurs at mountainous areas in Western China. They generally form and occur in where are featured with steep geomorphology, quantity of loose sediment accumulating, and abundant surface runoff [1]-[3]. It is often exasperated by extreme rainstorms [3]-[5], drastic exploitation activities and intensive earthquakes [1] [2] [6]-[9]. Some debris flows nearing villages, towns, cities, buildings, constructions and highway, often result in properties losses and a lot casualties, especially those large ones. When they occur in towns or urban areas, the losses and casualties are significantly exacerbated, as exemplified by the Venezuela mega debris flow in 2000, the Zhouqu debris flow in 2010 [10] [11] and the Aizi Gully debris flow at Ningnan County in 2012 [12]. For mountainous urban areas and towns, it is always a striking hot issue that predicts, prevents and controls debris flows, especially those at where are intensively disturbed by exploiting activities.

A group of disastrous debris flows occurred and threatened the city of Shimian, Sichuan province. They occurred at the gullies of Hou, Heilinzi and Xiongjia on July 4, 2013, and blocked the Nanya River as well as formed 3 lakes, endangering the city with a population of over 50,000 persons. These debris flows caused 18 casualties, destroyed and submerged more than 20 buildings, destructed the highway from Shimian to Xichang through G108 highway and interrupted the highway from Shimian to Ganluo. This work aimed to analyze characteristics, hazards and causes of these debris flows and provide suggestions and solutions for mitigation, contributing to debris flow hazards mitigating at urban areas of mountain.

\section{Study Area}

The gullies of Hou, Heilinzi and Xiongjia are located at the right bank of Nanya River, a tributary of Dadu River. Only $6 \mathrm{~km}$ upstream to the Shimian County (Figure 1), the three gullies are featured with high elevation difference, precipitous slopes, $\mathrm{V}$-shape gully and steep channel, which provide favorable dynamic condition for debris flow forming (Table 1). The strata of Sinian and Mesoproterozoic outcrop in the region, peridotite, basalt and granite predominate as well as limestone, dolomite, sandstone, shale, marble and sandy slate scatter. Moreover, massive of mining sediments deposited at slopes or along channels in the gullies of Hou and Xiongjia, and were of unconsolidated and unstable. In this region, the mean annual rainfall is about $1200.9 \mathrm{~mm}$, and $86.4 \%$ of that

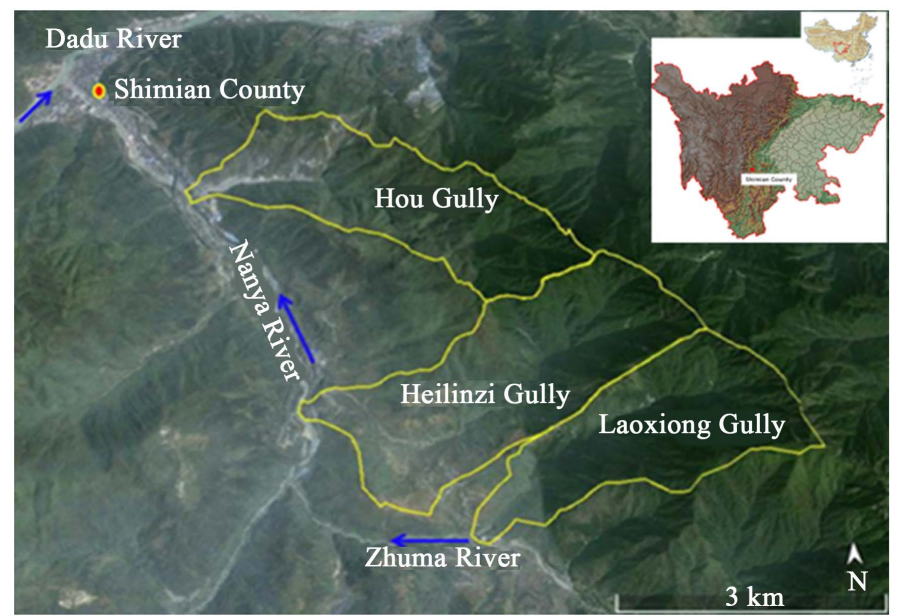

Figure 1. Location of study area.

Table 1. Geomorphologic parameters of debris flow gullies.

\begin{tabular}{ccccc}
\hline Name & Area $\left(\mathrm{km}^{2)}\right.$ & Elevation Difference $(\mathrm{m})$ & Channel Length $(\mathrm{km})$ & 6.42 \\
Hou Gully & 8.81 & 1879 & 6.19 & 30.9 \\
Heilinzi Gully & 8.23 & 1914 & 5.31 & 33.2 \\
Xiongjia Gully & 5.52 & 1795 & 5.3 \\
\hline
\end{tabular}


occurred from June to Sept, with many rainstorm. Moreover, in the most of gullies, the intensity of rainfall tends to increases with increasing altitude. Due to steep mountainous slopes, rainfall easily produces surface runoff and flash flood quickly, makes loose soil failing and initiates debris flow. Debris flows ever occurred in 1973, 1983, 1992, 1993, 1998 and 2004 at the Hou Gully [13], in 1973 at the Heilinzi Gully as well as in 1988 and 2008 at the Xiongjia Gully.

\section{Methodologies}

The remote-sense image with $4 \mathrm{~m}$ resolution from Google Earth was used to analyse geomorphology of gullies. Local observation rainfalldata from Shimian City and the outlets of three gullies were applied to confirm triggering conditions of hazard events. Six samples of debris flow deposits, with the quality of $3 \mathrm{~kg}$ each, were collected in the depositing areas to analyze particle size components and debris flow characteristics. The velocity and discharge of debris flow were calculated using the measured data of 6 cross-sections, using Laser-Distance Meter. Moreover, the discrimination models for debris flow blocking river was adopted to confirm the threshold of the main river blocking.

\subsection{Particle Size Components and Density}

Six samples from the deposits were collected, involving particle size up to $100 \mathrm{~mm}$. These samples were dried by wind and sunshine, and then were analyzed in conventional methods. Particles bigger than $0.5 \mathrm{~mm}$ are sorted by sieving ( $60 \mathrm{~mm}, 40 \mathrm{~mm}, 20 \mathrm{~mm}, 10 \mathrm{~mm}, 5 \mathrm{~mm}, 2 \mathrm{~mm}, 1 \mathrm{~mm}, 0.5 \mathrm{~mm}$ ) and particles smaller than $0.5 \mathrm{~mm}$ are measured using the laser granularity meter.

Then the density of debris flow was estimated by the Formula (1):

$$
\gamma_{D}=\gamma_{0}+P_{2} P_{05}^{0.35} \gamma_{V}
$$

where, $\gamma_{D}$ is the density of debris flow, $\gamma_{0}=1.5 \mathrm{t} / \mathrm{m}^{3}$ is assumed as the lowest density of debris flow, $\gamma_{V}=2.0 \mathrm{t} / \mathrm{m}^{3}$ is the lowest density of viscous debris flow, $P_{2}$ and $P_{05}$ is the grain percentage of more than $2 \mathrm{~mm}$ and less than $0.05 \mathrm{~mm}$, respectively [13]. This formula was established on the basis of many typical debris flows deposits in western China, which was proved valid for different debris flows except for mud flow and water-rock flow, and also applicable for debris flows in the Wenchuan Earthquake areas.

\subsection{Debris Flow Velocity and Discharge}

\subsubsection{Cross-Section Methodology}

The parameters of 6 cross-sections were measured using Laser Distance Meter for calculating the velocity and discharge of debris flows using the revised Manning formulae, which has been generally adopted:

$$
\begin{aligned}
V_{C} & =\frac{1}{n_{c}} H^{\frac{2}{3}} I^{\frac{1}{2}} \\
Q_{C} & =A_{C} V_{C}
\end{aligned}
$$

where $V_{C}$ is the peak velocity of debris flow at a cross section, $n_{c}$ is the roughness coefficient of gully channel, $H$ is the flow depth of debris flow, $I$ is the slope of gully channel near the cross section, $Q_{C}$ is the peak discharge, $A_{C}$ is the area of section. $n_{c}$ is confirmed according to the actual situation of channel [15].

\subsubsection{Rainstorm-Flood Methodology}

The discharge of debris flow was also calculated through the discharge of flash flood. This methodology considers both the influences of flash flood and the impacts of block and outburst of debris flow, which is induced by deposit bodies or natural dams at channels. The formulae are shown as follows [15]:

$$
\begin{gathered}
Q_{C}=(1+\varphi) Q_{B} q \\
\varphi=\left(\gamma_{D}-1\right) /\left(\gamma_{H}-\gamma_{D}\right)
\end{gathered}
$$


where $Q_{C}$ and $Q_{B}$ are the peak discharge of debris flow and flash flood, respectively, and $Q_{B}$ is calculated using the parameters of watershed or gully and the methodology that was represented by the Calculation Handbook of Flash Flood Induced by Rainstorm for Watersheds of Sichuan Province. $\varphi$ is the coefficient that is defined by [5]. $q$ is the amplification coefficient of debris flow, ranging from $1.0-5.0$, and confirmed according to the situation of channel blocks [16]. $\gamma_{D}$ is obtained by Formula (1), and $\gamma_{H}=2.65 \mathrm{t} / \mathrm{m}^{3}$ is the density of rocks in debris flow. When be lack of the data of cross-section in the channel, this formula is used to estimate the peak velocity and discharge of a debris flow. It is also adopted to predict peak discharges of debris flows that are triggered by different probability.

\subsection{Deposit Volume}

The deposit volume was estimated on the base of the surveyed data of field investigation and using the following empirical formula [15]:

$$
D_{S}=0.264\left(\gamma_{D}-\gamma_{W}\right) /\left(\gamma_{H}-\gamma_{W}\right) Q_{C} T
$$

where $D_{S}$ is the solid material volume that debris flow delivered into the lower of a cross section; $\gamma_{W}=1.0 \mathrm{t} / \mathrm{m}^{3}$ is the density of water flow, $T$ is the time of debris flow lasting (s), and the others are the same as mentioned above. Considering some deposits will be delivered by the following flash flood from the gully or the flood from the main river, the data from field measuring and the empirical are generally calibrated each other to obtain the approaching actual.

\subsection{Conditions of River Blocking}

\subsubsection{Debris Flow Discharge}

The formula for debris flows blocking river, established according to field data and laboratary experiments [17], was used to confirm the condition of debris flow blocking Nanya river :

$$
K=\left|\frac{\operatorname{Ln}\left(Q_{M} / Q_{P}\right)-0.883(1-\operatorname{Cos} \theta)^{2}-2.587 \gamma}{-8.572}\right|
$$

where $K$ is the coefficient of blocking, $Q_{M}$ is the unit width discharge of river $\left(\mathrm{m}^{3} / \mathrm{s} . \mathrm{m}\right), Q_{P}$ is the peak unit width discharge of debris flow $\left(\mathrm{m}^{3} / \mathrm{s} . \mathrm{m}\right), \theta$ is the junction angle of channels between river and debris flow gully, and $\gamma$ is the mass density ratio of debris flow to river flow. The river is blocked completely only when $K \geq 1$. Comparing this model with other model, the discharge-ratio discrimination model considers relationship between dynamic condition and geomorphology between debris flow gullies and the main river, could more reflect the actual and be adopted to discuss dynamic condition of debris flow blocking river [18].

\subsubsection{Debris Flow Deposition Volume}

Debris flow blocking river by forming a stable dam, for which the solid volume of debris flow, $Q_{C s}$ must satisfy the Formula (8) [16]:

$$
Q_{C s}=\left(\frac{1}{2 \operatorname{tg} 14^{\circ}}+\frac{1}{2 \operatorname{tg} \varphi_{s}}\right) B_{w} H_{w}^{2} \lambda
$$

where $\varphi_{s}=25^{\circ}$ is inner friction angle at saturation soil, $B_{w}$ is the width of Nanyan river and about $50 \mathrm{~m}, H_{w}$ is the flow depth of main river and about $5 \mathrm{~m}, \lambda$ is the correctional coefficient, equaling to 1.25 [19]. The revised formula considers the deposit that is delivered out of the outlet, which include that into the channel of main river and that in channel of the gully.

\section{Debris Flow Characteristics}

\subsection{High Density and Low Viscosity}

The grain size of debris flow deposit samples with smaller $0.05 \mathrm{~mm}$ (silt) and $0.005 \mathrm{~mm}$ (clay soil) was only about $0.9 \%-1.4 \%$ and $0.3 \%-0.6 \%$, respectively, and those bigger $2 \mathrm{~mm}$ ranged $61.7 \%$ from $78.3 \%$. Compar- 
ing to typical viscous debris flow, with up to $8 \%$ clay and up to $15 \%$ silt, the fine material content, including clay and silt, was much lower, which indicates these debris flows are lowly viscous. The materials with smaller $100 \mathrm{~mm}$ and the boulders with bigger $1 \mathrm{~m}$ occupied over $50-55 \%$ of solid materials and $3 \%-5 \%$, respectively. The density of debris flows, calculated by the formula [1], ranged from $1.77-1.84 \mathrm{t} / \mathrm{m}^{3}$ as shown in Table 2 . The data of particle sizes and densities of deposits expressed that debris flow were charaterized by lowly viscous and high-density.

\subsection{High Velocity and Large Discharge}

The calculated velocity and discharge were showed in Table 3 . The velocity of debris flow was $13.5 \mathrm{~m} / \mathrm{s}, 8.6$ $\mathrm{m} / \mathrm{s}$ at the outlet of Hou Gully and Heilinzi Gully, respectively, and decreased from $13.2 \mathrm{~m} / \mathrm{s}$ to $4.4 \mathrm{~m} / \mathrm{s}$ at Xiongjia Gully along Zhuma River channel. The peak discharges was $1248 \mathrm{~m}^{3} / \mathrm{s}, 827 \mathrm{~m}^{3} / \mathrm{s}$ and $1182 \mathrm{~m}^{3} / \mathrm{s}$, respectively, and those of Xiongjia Gully gradually reduced from $1182 \mathrm{~m}^{3} / \mathrm{s}$ into $384 \mathrm{~m}^{3} / \mathrm{s}$ along Zhuma River. The change of velocity and discharge of debris flow of the Xiongjia Gully indicated the dynamic process that debris flow moved out of the outlet of the gully and into the tributary of Nayan River. The data showed that debris flow continuously moved and gradually reduced velocity and discharge due to gentle and narrow channel as well as decreasing materials supplement. Compared the discharges of debris flows at the outlet with those under different probability (Table 4), it was found that those on July 4th at the gully outlets were over double of those of $0.2 \%$ probability, which indicated that debris flow probably experienced dramatic discharge amplification due to local geomorphology (Figure 2).

Table 2. Particle size and density of debris flows.

\begin{tabular}{|c|c|c|c|c|c|}
\hline Gully Name & $P_{005}(\%)$ & $P_{05}(\%)$ & $P_{2}(\%)$ & $P_{05}^{0.35}$ & $\gamma_{D}\left(\mathrm{t} / \mathrm{m}^{3}\right)$ \\
\hline \multirow{2}{*}{ Hou Gully } & 0.6 & 1.4 & 61.7 & 0.22 & 1.78 \\
\hline & 0.7 & 1.2 & 78.3 & 0.21 & 1.83 \\
\hline \multirow[t]{2}{*}{ Heilinzi Gully } & 0.5 & 1.1 & 66.5 & 0.21 & 1.77 \\
\hline & 0.6 & 1.1 & 72.7 & 0.21 & 1.80 \\
\hline \multirow[t]{2}{*}{ Xiongjia Gully } & 0.3 & 1.3 & 77 & 0.22 & 1.84 \\
\hline & 0.5 & 0.9 & 75.8 & 0.19 & 1.79 \\
\hline
\end{tabular}

$\mathrm{P}_{005}$ is the percentage of particles of $\leq 0.005 \mathrm{~mm}$.

Table 3. Velocity and discharge of debris flows.

\begin{tabular}{cccccc}
\hline Gully Name & $A c\left(\mathrm{~m}^{2}\right)$ & $H(\mathrm{~m})$ & $I(\%)$ & $V_{c}(\mathrm{~m} / \mathrm{s})$ & Qc $\left(\mathrm{m}^{3} / \mathrm{s}\right)$ \\
\hline Hou Gully & 93 & 7.7 & 12 & 13.5 & 1248 \\
Heilinzi Gully & 96 & 4.5 & 10 & 8.6 & 827 \\
& 89 & 6 & 9 & 13.2 & 1182 \\
Xiongjia Gully & 115 & 6.5 & 6.5 & 7.4 & 981 \\
& 71 & 4.7 & 3 & 4.4 & 327 \\
\hline
\end{tabular}

Table 4. Debris flow discharges at different probability.

\begin{tabular}{|c|c|c|c|c|c|}
\hline Gully Name & $5 \%\left(\mathrm{~m}^{3 /} \mathrm{s}\right)$ & $2 \%\left(\mathrm{~m}^{3} / \mathrm{s}\right)$ & $1 \%\left(\mathrm{~m}^{3} / \mathrm{s}\right)$ & $0.5 \%\left(\mathrm{~m}^{3} / \mathrm{s}\right)$ & $0.2 \%\left(\mathrm{~m}^{3} / \mathrm{s}\right)$ \\
\hline Hou Gully & 208 & 276 & 340 & 411 & 510 \\
\hline Heilinzi Gully & 201 & 267 & 328 & 396 & 492 \\
\hline Xiongjia Gully & 142 & 188 & 231 & 279 & 346 \\
\hline
\end{tabular}




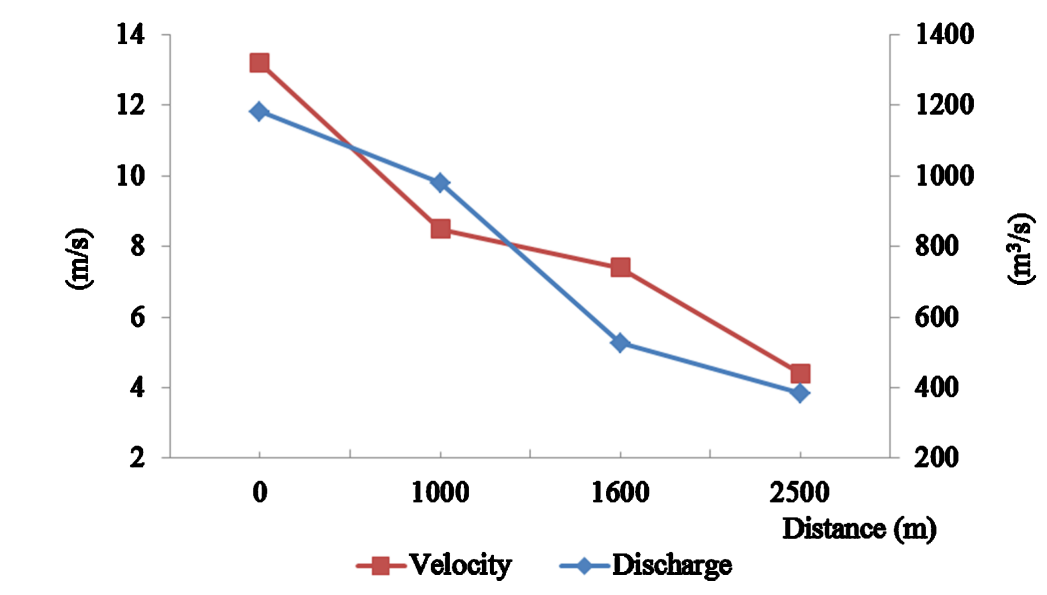

Figure 2. Change of velocity and discharge of Xiongjia Gully.

\subsection{Large Deposit Volume}

The debris flow deposit volume at the outlet was calculated using the formula [6] and the survey data by field investigation, respectively. In the Hou Gully, debris flow delivered about $23.4 \times 10^{4} \mathrm{~m}^{3}$ sediment and about $16.8 \times$ $10^{4} \mathrm{~m}^{3}$ moved out and deposited in Nanya River. In the Heilinzi Gully, about $12.7-13.5 \times 10^{4} \mathrm{~m}^{3}$ sediment was delivered into the Nanya River, blocking river. In the Xiongjia Gully, debris flow transported $20.5 \times 10^{4} \mathrm{~m}^{3}$ sediment, of which $10.8 \times 10^{4} \mathrm{~m}^{3}$ blocked Zhuma River and produced a dammed lake, about $4.2 \times 10^{4} \mathrm{~m}^{3}$ deposited along the $2.5 \mathrm{~km}$ channel of Zhuma River and $5.5 \times 10^{4} \mathrm{~m}^{3}$ was further delivered into the Nanya River and blocked the river. All these debris flows were large-magnitude, and those at Hou and Heilinzi gullies were of low frequency.

\subsection{Hazard Chain Process}

Due to limited and narrow geomorphology in mountainous areas, the large debris flow, with high-velocity, largedischarge and big-volume, generally forms hazard chains, whose common process involves in flash flood, channelized debris flow, dammed lake and outburst flood. Whether debris flow blocking river or not mainly depend on the dynamic condition of debris flow and of river flow and the amount of deposit into river channel. According to the formulas [7] and [8], the threshold of the unit width discharge and the deposit volume for blocking river were $37.0 \mathrm{~m}^{3} / \mathrm{s} . \mathrm{m}$ and $4500 \mathrm{~m}^{3}$, respectively. These criterions were all satisfied by the three debris flows. The unit width peak discharge at the outlet of Hou, Heilinzi and Xiongjia Gullies was $41 \mathrm{~m}^{3} / \mathrm{s} . \mathrm{m}, 43.5$ $\mathrm{m}^{3} / \mathrm{s} . \mathrm{m}$ and $40 \mathrm{~m}^{3} / \mathrm{s} . \mathrm{m}$, respectively, and the deposit volume reached $16.8 \times 10^{4} \mathrm{~m}^{3}, 12.7-13.5 \times 10^{4} \mathrm{~m}^{3}$ and $5.5 \times$ $10^{4} \mathrm{~m}^{3}$, respectively. Therefore, the three debris flows generated 3 lakes along $6 \mathrm{~km}$ channel of Nanya River. In particularly, the dammed lake by Hou Gully debris flow directly endangered the downstream city with a population of 50,000. Moreover, the large debris flow of Xiongjia Gully not only dammed Zhuma River but also blocked Nanya River, which involved in the process of flash flood and channelized debris flow in the Xiongjiagully, dammed lake, outburst flood and outburst debris flow in the Zhumu River, dammed lake and outburst flood in the Nanya River. .

\section{Destructing Modes}

Debris flows and the following hazards made serious property destructing and loss and causalities by impacting, scouring, burying and channel rising.

\subsection{Impacting and Scouring}

The debris flows generally intensely impacted and scoured constructions and buildings along the channel and destructed them partially and even completely. All the prevention walls and storage dams for debris flow mitigating in the Hou Gully were destructed by frontal impacting, lateral scouring and bottom eroding (Figure 3). The debris flows of the Heilinzi Gully impacted the 18 families' houses at the outlet and along the highway of 


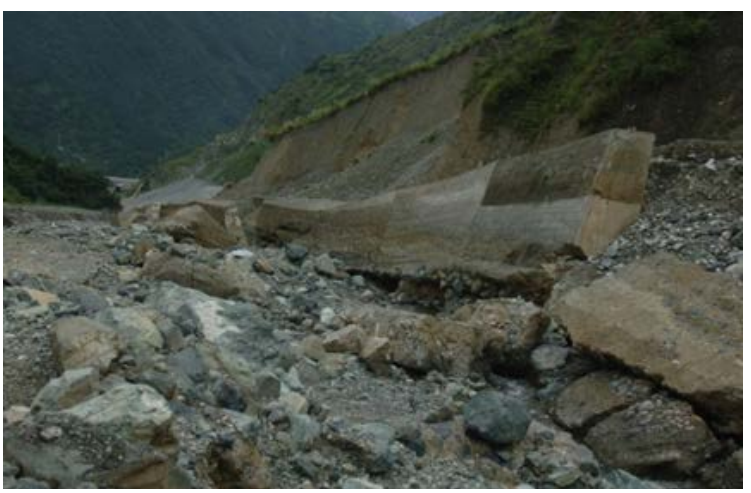

Figure 3. Destructed prevention wall at the Hou Gully channel.

G108, resulting in 3 casualties. Moreover, the constructions along the upstream channel were also destructed to some extent. The debris flow of Xiongjia Gully, with large-discharge and intensive breaching capability, climbed $16 \mathrm{~m}$ high along the terrace at the outlet, breached 3 families houses of Shilong Village and 3 buildings with 4 floors, resulting in 15 casualties (Figure 4). Moreover, the outburst debris flow and outburst flood also intensively scoured some buildings and farmlands in downstream channel along the Zhuma River.

\subsection{Burying}

Debris flow deposits in the depositing area and in the gentle channel to make constructions burying. Many buildings, houses and fruit farmland along channels and at the deposition areas of debris flow were buried in these three gullies. The drainage flumes of the three gullies were buried, allowing debris flow deviating from the channels (Figure 5 and Figure 6). Most houses and farmland at deposition fans were destructed by debris flow of low velocity and small discharge. Moreover, the later debris flow with lower velocity and fine sediment also resulted in channel rise and buried some of properties.

\subsection{Highway Destructing}

Highway destruction and traffic interruption originated from pavement burying and bridge breaching. The debris flow from the Hou Gully blocked culvert and deposited on the G108 highway base with 2 - $12 \mathrm{~m}$ high, resulting in $200 \mathrm{~m}$ highway destructing. The debris flows of Heilinzi Gully buried $80 \mathrm{~m}$ G108 highway due to the block of small bridge and made traffic interrupted temperately. The debris flow of Xiongjia Gully ruined a small bridge at the outlet and buried highway for $80 \mathrm{~m}$, resulting in the traffic from Shimian to Ganluo halting.

\subsection{River Channel Rising}

The three step-dammed lakes at Nanya River, which were induced by debris flows, made river channel dramatically rise. The three debris flow dams, with 200 - $300 \mathrm{~m}$ long and 5 - $6 \mathrm{~m}$ high, blocked flow, produced dammed lakes and outburst flood as well as further delivered sediment from dams to deposit in the downstream channel so that river channel rose by 1 - $2 \mathrm{~m}$ in over $6 \mathrm{~km}$ channel (Figure 7). The outburst debris flow of Xiongjia Gully dammed lake made $2500 \mathrm{~m}$ Zhuma River channel rise for 1 - $3 \mathrm{~m}$. River channel rising further enlarged the hazard zone of outburst debris flow and outburst flood to make more constructions and farmlands submerged and ruined. For example, the two water power stations along the Zhuma River and some factories along the Nanya River.

\section{Hazard Causes}

\subsection{Natural Causes}

Debris flow occurrence depends on the interaction of loose soil and surface runoff. The investigation showed that the loose soil was abundant but originated from various sources in these three gullies. In the Hou Gully, loose soil not only originated from landslides and slope deposits along upstream channels, but also from slope deposits, eluvium and mining wastes along the downstream channels. They distributed along $1.7 \mathrm{~km}$ channel with 20 - 


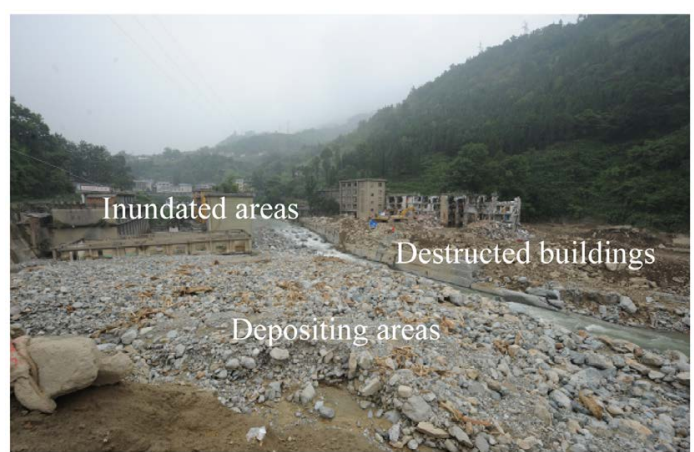

Figure 4. Destructed buildings at the Xiongjia Gully outlet.

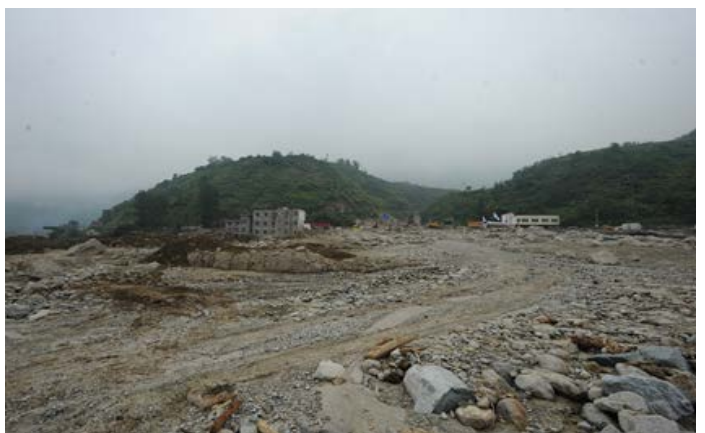

Figure 5. Buried houses and farmlands at the outlet of the Heilinzi Gully.

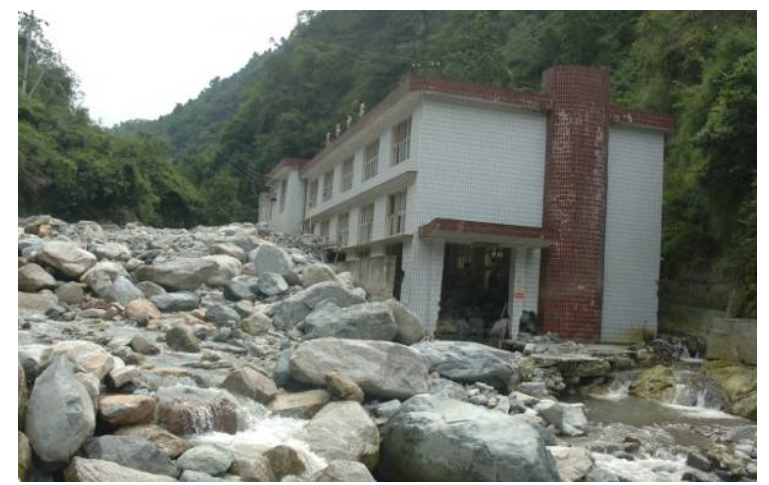

Figure 6. Outburst debris flow buried the Heiqiao power station.

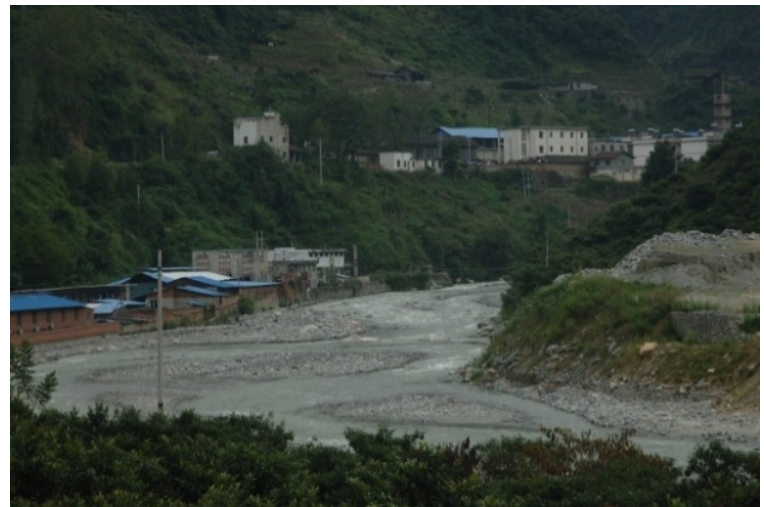

Figure 7. Nanya river channel rise induced by debris flows. 
$40 \mathrm{~m}$ high and 20 - $30 \mathrm{~m}$ width, and the accumulation volume of deposits account for 3.79 million $\mathrm{m}^{3}$. Compared with natural soil, the mining waste deposits is unconsolidated and very easily to initiate debris flow under intensive rainfall. However, the loose soil of Heilinzi Gully and Xiongjia Gully were mainly provided by landslides, rock falls and slope deposits in the middle and upper reaches, channel base initiating and redelivery. Mining wastes were also materials of debris flow but not majority.

The intense rainfall and rainstorm occurred at 18:00 - 21:00 and about 20:00 - 20:30, respectively, on July 4 and initiated debris flows. The rainfall data of Shimian showed that the antecedent rainfall and the triggering rainfall were $52 \mathrm{~mm}$ and $36.6 \mathrm{~mm} / \mathrm{h}$, respectively. The rainfall in the gullies of Hou, Heilinzi and Xiongjia was $80.9 \mathrm{~mm}, 62.0 \mathrm{~mm}$ and $53.9 \mathrm{~mm}$, respectively, which was measured at gully outlet and lower than the triggering rainfalls of debris flow in the forming areas and source areas due to vertical difference of local rainfall. Local rainstorm, which concentrated in source areas, rapidly produced surface runoff and flash flood in channels, and initiated saturated loose sediments to form debris flows in slopes and channels. Then, debris flow grew continuously and enlarged itself to become large-scale channelized debris flows, which experienced the process of jam and outburst of dams slope deposits, slope debris flow converging and initiating and redelivery of channel bed.

\subsection{Irrational Location}

To some extent, the catastrophic losses were generated by irrational location of houses and buildings due to the ignorance of the hazard zone and level of debris flows. The destruction of buildings and houses and the casualties at the Heilinzi and Xiongjia Gullies originated from their location in high-hazard zone, but not be identified in advance. Furthermore, the two water power stations, named by Tiaofeng and Heiqiao, were destructed by outburst debris flow because they were constructed along Zhuma River channel, not considering river channel rise aggradation. In the Heilinzi Gully, 18 families along channel were ruined and resulted in 3 casualties because that local people did not predict so large and disastrous debris flow event in this gully.

\subsection{Prevention Structures Destruction}

The serious destruction of prevention structures and constructions were responsible for huge losses in the gullies of Hou and Xiongjia. The debris flow scoured and destructed $1.7 \mathrm{~km}$ concrete prevention wall with $5 \mathrm{~m}$ high and 1 - $3 \mathrm{~m}$ thick. The $1.7 \mathrm{~km}$ step-dams, which were made by rock-filled wire gabion with the interval of $30 \mathrm{~m}$ and $3 \mathrm{~m}$ high, were intensely scoured and mostly destructed. Moreover, the drainage flume, with $3 \mathrm{~m}$ deep and $9 \mathrm{~m}$ wide, had not the capability of discharge debris flow sharply so that debris flow overflowed, resulting in the buildings along channel being seriously destructed (Figure 8). Additionally, the bridges or culverts at the outlets of the gullies of Hou, Heilinzi and Xiongjia could not provide appropriate drainage section for debris flows, and they were blocked so that debris flow buried highway base. As a result, the traffic from Shimian to Xichang and Ganluo was interrupted.

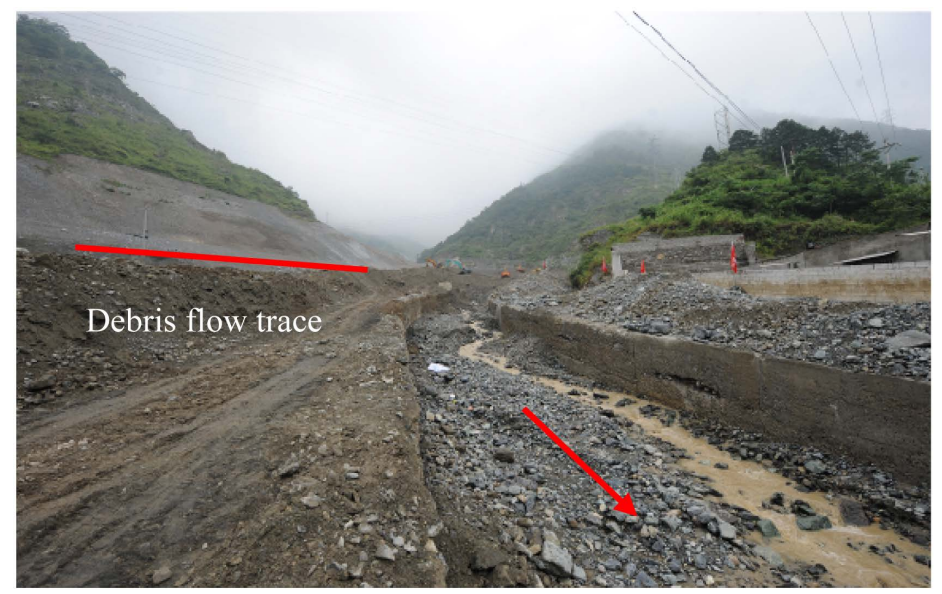

Figure 8. Debris flow buried drainage flume in the Hou Gully. 


\section{Prevention Measures}

\subsection{Hazard Reassessment}

Debris flows will be active in the three gullies after these events due to dramatic destruction of local environment. It is strongly suggested that debris flow hazard be assessed in the three gullies and the nearing gullies by analyzing formation conditions of debris flows and human activities, especially discovering the distribution and estimating the amount of loose soil and mining wastes as well as calculating the probable peak discharge and deposit volume. The hazard zoning is made at each gully, and the low-hazard and middle-hazard zones are selected to serve for reconstruction and exploitation. Moreover, the buildings and constructions in high-hazard zones are suggested to be relocated.

\subsection{Integrated Control}

Since these three gullies are close to Shimian City and villages, integrated measures should be carried out to control debris flows by optimizing engineering and biology measures to fix soil, store the sediment and drain flow according to kinetic characteristics of debris flows. The principle for debris flow process regulating should be adopted to control the discharges along channel and deposit volume in the outlet at different gully section, prevent hazard chain and reduce losses.

\subsection{Emergency Plan}

The emergency plans for hazards mitigating including monitoring, alarming, refuging, succoring, and reconstructing are strongly suggested to be established and improve the capabilities of hazards prevention of local people. And the emergency plans are required to be built in community unit and form mitigation network, which not only inspire the activities of local people but also exert the functions of local governments.

\subsection{Risk Management}

Considering the hazards of debris flows on Shimian County, the following works must be carried out, including risk assessment, risk monitoring, exploitation supervising and mining wastes processing, which are necessary to provide a valuable solution to hazard identification, hazard evaluation, risk assessment and risk control for mountainous urban areas.

\section{Conclusion}

The three disastrous debris flows on July 4 2013, triggered by intense rainstorm with the rainfall of over $36 \mathrm{~mm}$ per hour, were characterized by low viscosity, density of $1.77-1.84 \mathrm{t} / \mathrm{m}^{3}$, velocity of from $4.4-13.5 \mathrm{~m} / \mathrm{s}$ and discharge of $827-1248 \mathrm{~m}^{3} / \mathrm{s}$, and delivered sediment of $16.8 \times 10^{4} \mathrm{~m}^{3}, 12.7-13.5 \times 10^{4} \mathrm{~m}^{3}$ and $20.5 \times 10^{4} \mathrm{~m}^{3}$ out of the outlet, respectively. They also involved a hazard chain which is composed by flash flood, debris flow, dammed lake and outburst flood. When the unit width discharge and the deposition volume in the channel are more than $37.0 \mathrm{~m}^{3} / \mathrm{s}$ and $4500 \mathrm{~m}^{3}$, respectively, debris flow can block Nanya River and form this hazard chain. The irrational location of constructions and the destruction of under-standard prevention constructions were responsible for loss worsening. For debris flow hazard mitigating at the urban areas, hazards reassessment, integrated control, emergency plan and risk integrated management were strongly recommended.

\section{Acknowledgements}

This work was jointly supported by the National Natural Science Foundation Program of China (Program No. 41171012) and (Program No. 41471010). The authors are very grateful for the help of Prof. Xiaoqing Chen, from Institute of Mountain Hazards and Environment, CAS, who provide valuable data.

\section{References}

[1] Cui, P., Chen, X.Q., Zhu, Y.Y., et al. (2011) The Wenchuan Earthquake (May 12, 2008), Sichuan Province, China, and Resulting Geohazards. Natural Hazards, 56, 19-36. http://dx.doi.org/10.1007/s11069-009-9392-1

[2] Cui, P., He, S.M., Yao, L.K., et al. (2011) Formation Mechanism and Risk Control of Mountain Hazards Induced by 
the Wenchuan Earthquake. Science Press, Beijing. (In Chinese)

[3] De Graff, J., Wagner, D., Gallegos, A., et al. (2011)The Remarkable Occurrence of Large Rainfall-Induced Debris Flows at Two Different Locations on July 12, 2008, Southern Sierra Nevada, CA, USA. Landslides, 8, 343-353. http://dx.doi.org/10.1007/s10346-010-0245-5

[4] Guzzetti, F., Peruccacci, S., Rossi, M., et al. (2008) The Rainfall Intensity-Duration Control of Shallow Landslides and Debris Flows: An Update. Landslides, 5, 3-17. http://dx.doi.org/10.1007/s10346-007-0112-1

[5] Huang, C.C. (2013) Critical Rainfall for Typhoon-Induced Debrisflows in the Western Foothills, Taiwan. Geomorphology, 185, 87-95.

[6] Chen, N.S., Yang, C.L., Zhou, W., et al. (2009) The Critical Rainfall Characteristics for Torrents and Debris Flows in the Wenchuan Earthquake Stricken Area. Journal of Mountain Science, 6, 362-372. http://dx.doi.org/10.1007/s11629-009-1064-9

[7] Liu, C.N., Huang, H.F. and Dong, J.J. (2008) Impacts of September 21, 1999 Chi-Chi Earthquake on the Characteristics of Gully-Type Debris Flows in Central Taiwan. Natural Hazards, 47, 349-368. http://dx.doi.org/10.1007/s11069-008-9223-9

[8] Piper, D.J.W., Cochonat, P. and Morrison, M. (1999) The Sequence of Events around the Epicentre of the 1929 Grand Bank Earthquake: Initiation of Debris Flows and Turbidity Current Inferred from Sidescan Sonar. Sedimentology, 46, 79-97.

[9] Kentens, K.A. (1984) Earthquakes as a Triggering Mechanism for Debris Flows and Turbidites on the Calabrian Ridge. Marine Geology, 55, 13-33.

[10] Cui, P., Zhou, G.G.D., Zhu, X.H., et al. (2013) Scale Amplification of Natural Debris Flows Caused by Cascading Landslide Dam Failures. Geomorphology, 182, 173-189. http://dx.doi.org/10.1016/j.geomorph.2012.11.009

[11] Tang, C., Rengers, N., Asch, T.W.J., et al. (2011) Triggering Conditions and Depositional Characteristics of a Disastrous Debris Flow Event in Zhouqu City, Gansu Province, Northwestern China. Natural Hazards and Earth System Science, 11, 2903-2912. http://dx.doi.org/10.1007/s10346-011-0269-5

[12] Hu, K.H., Cui, P., Ma, C., et al. (2012) Causes and Characteristics of 28 June Disastrous Debris Flow Event in Ningnan County of Sichuan, China. Journal of Mountain Science, 30, 696-700. (In Chinese)

[13] Ni, H.Y., Zheng, W.M., Ba, R.J., et al. (2010) Formation and Characteristics ofM ine Debris Flows Based on Dynamic Conditions-A Case Study of Hou Gully in Shimian County, Sichuan Province. Journal of Mountain Science, 28, 460477. (In Chinese)

[14] Yu, B. (2008) Research on the Calculating Density by the Deposit of Debris Flows. Acta Sedimentolgica Sinica, 26, 789-796. (In Chinese)

[15] Tang, B.X., Zhou, B.F., Wu, J.S., et al. (2000) Debris Flow in China. The Commercial Press, Beijing. (In Chinese)

[16] Zhou, B.F., Li, D.J., Luo, D.F., et al. (1991) Guide of Debris Flow Control. Science Press, Beijing. (In Chinese)

[17] He, Y.P., Guo, Z.X., Li, Y., et al. (2005) Flume Experiment on Stream Blockage Caused by Tributary Debris Flow. Journal of Sichuan University (Engineering Science Edition), 37, 64-70. (In Chinese)

[18] Liu, C.R., Yao, L.K., Chen, C.G., et al. (2012) Criterion and Patterns of Debris Flow Blocking Big River Based on Water and Sediment Dynamic Processes. Journal of Hydraulic Engineering, 43, 122-127. (In Chinese)

[19] Zhuang, J.Q., Cui, P., Ge, Y.G., et al. (2010) Probability Assessment of River Blocking by Debris Flow Associated with the Wenchuan Earthquake. International Journal of Remote Sensing, 31, 3465-3478. http://dx.doi.org/10.1080/01431161003730873 